\title{
ULTRASTRUCTURAL CHANGES IN SEROMUCOUS ACINI OF RAT SUBMANDIBULAR GLAND AFTER CHORDA TYMPANI NEURECTOMY
}

\author{
By \\ Ibrahim A. Shaaban, Abdel Hakim Z. Gabr, \\ Hanan A. El Gendy and Raouf F. Beder \\ Anatomy Department, faculty Of Medicine, Mansoura University
}

\section{INTRODUCTION}

The main parasympathetic innervation to submandibular salivary gland, via the chorda tympani, is necessary for maintenance of the normal integrity of parenchymatous elements (Barton et al., 1975; Calvert et al., 1998). The parasympathetic (secreto-motor) fibers pass through the chorda tympani branch of facial nerve and runs in the middle ear close to the posterior border of the inner surface of the tympanic membrane opposite the upper end of the manubrium mallei (Perwaiz and Karim, 1982). It leaves the skull through the petrotympanic fissure to join the posterior border of the lingual nerve at an acute angle, then to submandibular ganglion where it relays. The postganglionic fibers pass directly to the submandibular gland (Williams et al., 1995).

Interruption of parasympathetic nerve supply to the submandibular gland through destruction of chorda tympani resulted in atrophy of the submandibular and sublingual glands (Kyriacou an Garrett, 1988) and reduction of their secretory function (Zalin and Cooney, 1974). However, Carpenter et al. (2000) as well as Boron and Boul Peep (2003) reported that the secretory response of the gland was not completely abolished by cutting chorda tympani nerve, but was reduced and hence suggested that other parasympathetic pathways for the submandibular gland by other routes than the chorda tympani nerve. The observations of Garrett and Kyriacou (1988) suggested that the postganglionic.parasympathetic secretory fibers reach the rat submandibular gland by other routes beside the chorda tympani nerve. It was found also that reflexly induced submandibular secretion was not abolished by transection of chorda tympani nerve, but reduced to about half of the normal (Izumi and Karrita, 1994). Perwaiz and Karim (1982), in their histochemical studies, detected some cholinesterase positive nerves in association with the acini after sympathectomy and avulsion of the chorda tympani nerve. Anderson and Garrett (1998) as well as Hanna et al. (1999) considered that presence of cholinergic secretory nerve fibers innervating the gland and accompanying the blood vessels of the gland through the connection between lingual nerve and cho- 
linergic nerve strands on the blood vessels of the submandibular gland. Hellman and Stomblad (1960) considered that there is parasympathetic nerve supply from routes other than the chorda tympani nerve to the submandibular gland, although this pathway is unknown. Moreover, the submandibular gland may receive secretory fibers from the chorda tympani of both sides (Perwaiz and Karim, 1982). Recently, it was observed that the secretory response remaining after transection of chorda tympani nerve greatly diminished by cutting nerve strands to lingual nerve (Sato et al., 2001). Electrical stimulation of these strands caused a flow of saliva, which was not affected by ganglion blocking agents, but disappeared after atropine injection (Holmberg, 1971).

By the aid of light and electron microscope, the present study was undertaken to determine the presence or absence of persisting normal acini beside the affected one after cutting the chorda tympani nerve to declare if the gland receives parasympathetic supply by routes other than the chorda tympani nerve.

\section{MATERIALS AND METHODS}

\section{Animals:}

Twenty adult male rats were used in this study. Fifteen rats were exposed to cutting the right chorda tympani nerve by transtympanic neurectomy. The other five rats were subjected to sham operation for right ear and were used as a control group.

\section{Anesthesia:}

The rats were anaesthetized by intraperitoneal injection of sodium thiopentone $(35 \mathrm{mg} / \mathrm{kg}$ body weight), mixed with atropine sulphate $(0.05$ $\mathrm{mg} /$ body weight).

\section{Surgical Procedure:}

Chorda tympani neurectomy was performed according to the procedure of Kopka et al. (2000) through a deep vertical incision in the vertical part of the right external auditory tube to expose the horizontal part of this tube. With the aid of dissecting microscope, the tympanic membrane was visualized and the chorda tympani was identified as it passes through this membrane. The nerve was exposed, a sufficient segment of the nerve was excised and the central segment was avulsed to prevent post-operative regeneration. The tissues were replaced to their anatomical position and the wound closed with 5-0 silk sutures. 


\section{Post-operative care:}

The rats were given $0.1 \mathrm{ml}$ penicillin $\mathrm{G}$ benzathine intramuscular to prevent infection. The rats were given food and water ad libitum until the date of scarification.

\section{Histological methods:}

The animals were sacrificed at 2, 4, and 8 weeks after the operation. At the assigned time, the animals were anaesthetized (as before) and the right submandibular glands were thoroughly dissected out and removed. Specimens of the gland were prepared for paraffin sections, then were cut at 8-10 $\mu \mathrm{m}$ and stained with haematoxylin and eosin and PAS stains. Other specimens of the gland were taken and prepared for Electron Microscopy study. Small pieces of tissue about $1 \mathrm{~mm}^{3}$ were immersed in $2 \%$ paraformaldehyde $-1.25 \%$ glutaraldhyde for 1 hour, then immersed in $1 \%$ osmium tetroxide for $1-2$ hours at $4^{\circ} \mathrm{C}$, dehydrated with acetone, stained en bloc with 4\% Uranyl acetate and embedded in Epon 812 (Structure Probe, Westchester, PA, USA). Semi-thin sections $(1 \mu \mathrm{m})$ were cut and stained by toluidine blue. Ultra thin sections were cut on copper grids and stained with Uranyl acetate and lead citrate and examined under a Phillips EM208s transmission electron microscope (Luft, 1961; Millonig, 1961; Hayat, 1970).

\section{RESULTS}

\section{1- Control submandibular glands}

\section{Haematoxylin and eosin sections:}

The gland is divided by loose connective tissue septa into lobules. The lobules consist of secretory acini which are predominantly seromucous, and intercalated, granular convoluted and striated ducts (fig. 1). The serous acini are lined by large pyramidal cells with largely deeply stained basophilic nuclei towards the base of cells (Fig. 2).

\section{Periodic Acid Schiff (PAS) stained sections:}

PAS positive reaction was noted in the supranuclear region of the cytoplasm of the acinar and striated ductal cells, in the lumina of the majority of acini and darkly stained granules in the apical portion of the granular convoluted tubules (Fig. 3). 


\section{Semi-thin sections stained with toluidine blue:}

The semi-thin sections of control submandibular gland showed the presence of acini containing blue stained nuclei. The granular convoluted duct cells contain heterogenous size and shape of dark blue granules in the supranuclear cytoplasm (Fig. 4).

\section{Electron Microscope:}

The ultra-thin sections of the control acinar cells contain basally located nucleus surrounded by an abundant amount of rough endoplasmic reticulum and mitochondria with appearance of cristae in mitochondrial matrix. Plenty of variable dark spherical shape zymogen granules were seen in the apical cytoplasm (Figs. 5,6).

\section{II- Experimental group}

\section{A. 2 weeks after operation:}

\section{Haematoxylin and eosin sections:}

The acini were lined by small shrunken cells with scanty nongranular cytoplasm, and small deeply stained nuclei. The striated ducts lost its basal striation and the connective tissue increased around the acini and ducts. The interlobular ducts were dilated and lined by degenerated cells (Figs. 7 , 8). Apoptotic bodies were seen in the acini and around the ducts.

Semi-thin sections stained with toluidine blue showed shrunken acinar cells with scanty non-granular cytoplasm. The granular convoluted tubules contained less number of dark blue granules in the supranuclear cytoplasm (Fig. 9).

Electron Microscope after chorda tympani neurectomy showed acinar cells contain irregular nucleus with heterogenic chromatin condensation, degenerated mitochondria with loss of its cristae, presence of few zymogen granules and secretory granules variable in diameter and few vacuoles in the cytoplasm (Fig. 10). The basement membrane was thick and many irregular folds projected into wide intercellular space (Fig. 11).

\section{B. 4 weeks after operation:}

\section{Haematoxylin and eosin sections:}

The intralobular interstitial connective tissue increased in thickness (Fig. 12). The cells of atrophied acini were shrunken and contained scanty nongranular vacuolated cytoplasm with small deeply stained nuclei and apoptotic bodies were seen. Dilated and degenerated interlobular ducts were present and the striated ducts had lost their basal striations (Fig. 13). 
Semi-thin sections stained with toluidine blue showed atrophic acinar cells with vacuolated cytoplasm. The striated ducts had wider lumen and lined by cells with vacuolated cytoplasm. Their nuclei were small and arranged in more than one layer with loss of their basal striations (Fig. 14).

Electron Microscop showed degenerated acinar cells contain irregular nucleus, degenerated mitochondria, plenty of vacuoles, few zymogen granules, thick basement membrane and dilated rough endoplasmic reticulum. Phagocytosed apoptotic bodies were seen in the field (Figs. 15, 16).

\section{8 weeks after operation:}

Haematoxylin and eosin sections showed marked increase of connective tissue around the lobules and acini (fig. 17). Most of the acini were shrunken and contained vacuolated cytoplasm with small deeply stained nuclei. The striated and intercalated ducts were dilated and lined by degenerated cells (Fig. 18).

Semi-thin sections stained with toluidine blue showed marked atrophy of acinar cells which became shrunken with nongranular and vacuolated cytoplasm. Atrophied dilated striated ducts were lined by degenerated vacuolated cells. Their nuclei were small and arranged in more than one layer. The secretory granules of the granular convoluted tubules disappeared (Fig. 19).

Electron Microscop showed marked atrophic changes in the acinar cells which contained irregular nucleus with chromatin condensed into dense bodies and marked decrease of zymogen granules (Fig. 20). Many acinar cells contained degenerated mitochondria, excess vacuoles, increased electron density of the cytoplasm, dilated rough endoplasmic reticulum and phagocytosed apoptotic bodies (Fig 21).

Periodic Acid Schiff (PAS) stained sections after chorda tympani neurectomy showed weak PAS positive reaction in the cytoplasmic granules of the affected acinar and ductal cells. The granular convoluted tubules showed moderate PAS reaction in their ductal cells 2 weeks, 4 weeks and 8 weeks after chorda tympani neurectomy (Figs. 22, 23, 24).

By light microscopy and E. M examination, few persisting acini were seen among atrophic ones in the submandibular glands 2, 4 and 8 weeks after chorda tympani neurectomy (Figs. $8,10,13,14,18,19,21$ ). 


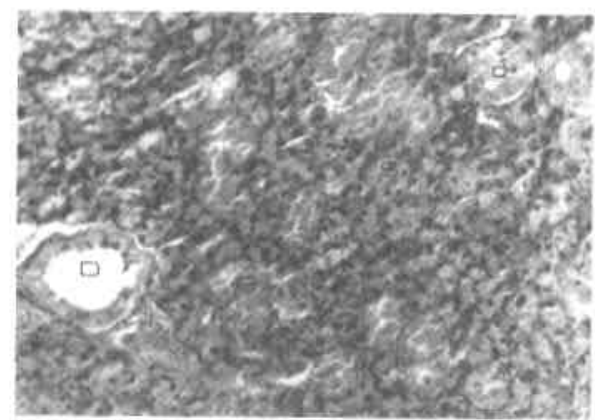

Fig. (1): A photomicrograph of a section of control rat submandibular gland. The gland lobule contains packed seromucous acini (S), striated (d) and interlobular (D) ducts and granular convoluted tubules (G). (HX. \& E.: X100)

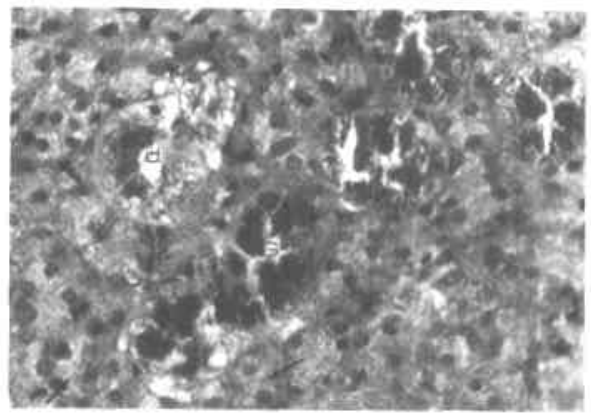

Fig. (3): A photomicrograph of a section of control rat submandibular gland. PAS positive reaction of supranuclear granules of the acinar cells (arrows). The apical portion of granular convoluted tubules (G) contains darkly stained granules and strong reaction in striated ducts (d). (PAS; $X$ 400)

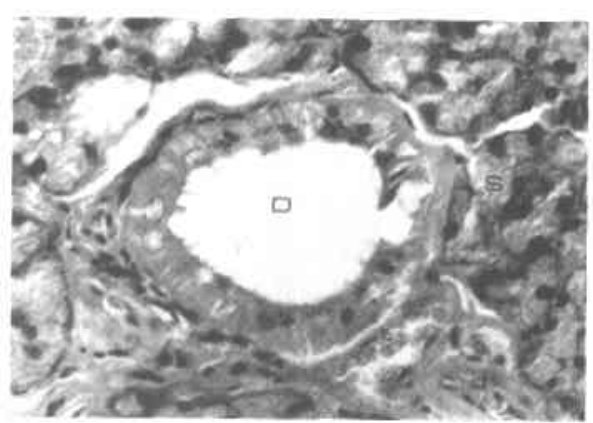

Fig. (2): A higher magnification of Fig. (1) Showing, the serous acini (S) are lined by pyramidal cells with basal large deeply stained nuclei. Note: striated duct (d) and interlobular duct (D). (HX. \& E.: X 400)

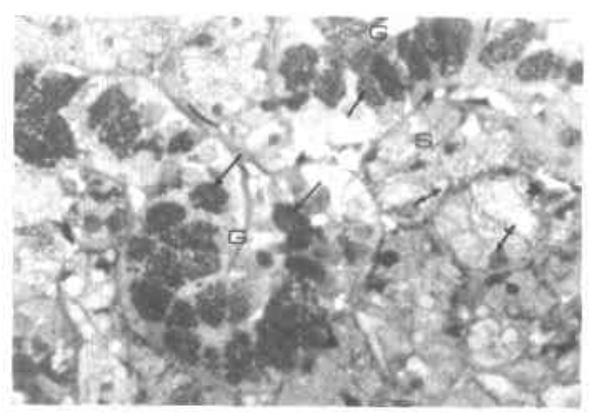

Fig. (4): A photomicrograph of semithin section in submandibular gland of control rat. Acinar cells (S) with blue stained nucleus (crossed arrow). The granular convoluted duct (G) contains heterogeneous size and shape of dark blue granules (arrows) in supranuclear part of cytoplasm. (Toluidine blue; $X 1000$ ) 


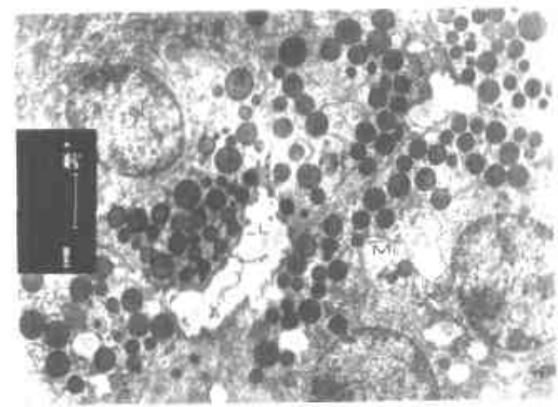

Fig. (5): An electronmicrograph of control rat submandibular gland, showing acinar cells contain round regular nucleus $(\mathrm{N})$ situated basally and surrounded by rough endoplasmic reticulum (rER), clearly visualized mitochondria $(\mathrm{m})$, plenty of dark spherical zymogene granules (Z) packed in the apical cyloplasm and the lumen (L) of the acinus. (X 6,000 )

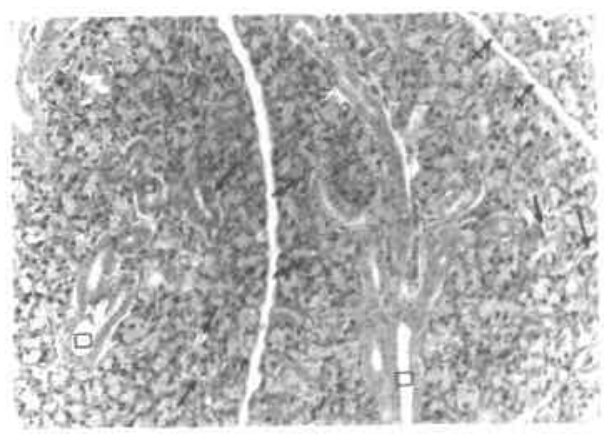

Fig. (7): A photomicrograph of a section in submandibular gland of rat 2 weeks after chorda tympani neurectomy. Note: increased connective tissue septa around acini (arrows) and interlobular septa (crossed arrows), dilated interlobular (D) and striated ducts (d). (HX. \& E.; X 100)

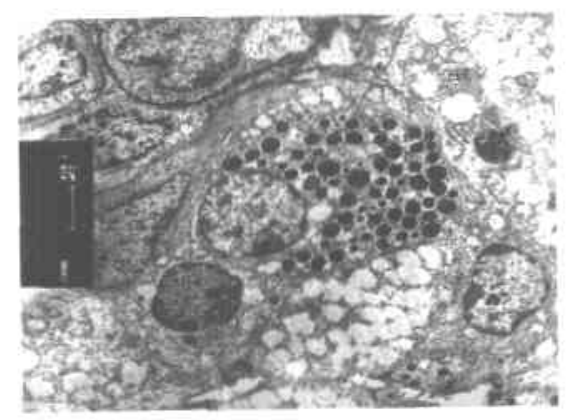

Fig. (6): An electronmicrograph of control rat submandibular gland, showing seromucous cell with abundant rough endoplasmic reticulum (rER), nucleus $(N)$, mitochondria $(M)$, vacuoles $(V)$ and plenty of dark spherical zymogen granules (Z) . $(X 6,000)$

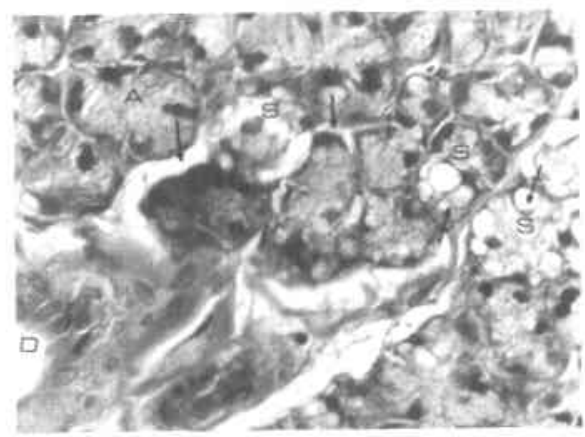

Fig (8): A photomicrograph of a section of rat submandibular gland 2 weeks after operation, showing atrophic non-granular cytoplasm (crossed arrows) of cells lining the seromucous acini (S) with increased amount of C.T. septa (arrows) around the acini and presence of apoptotic bodies (head arrows). The interlobular ducts (D) appeared dilated and lined with atrophic epithelial cells. Presence of intact acini (A). (HX \& EX 400) 


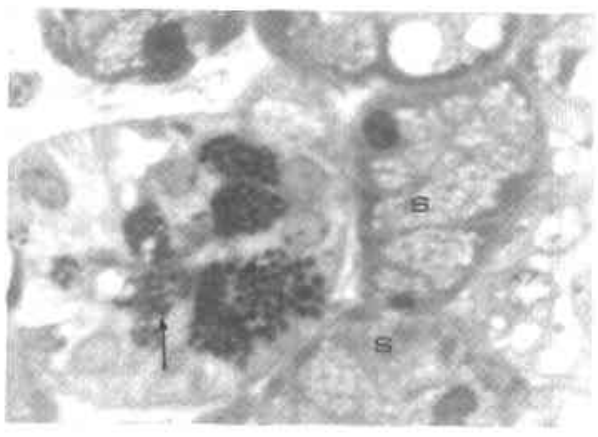

Fig. (9): A photomicrograph of semi-thin section in submandibular gland of rat 2 weeks after operation, showing degenerated seromucous acini (S) and decrease of dark blue granules in granular convoluted duct (arrow). (Toluidine blue; $X 1000$ )

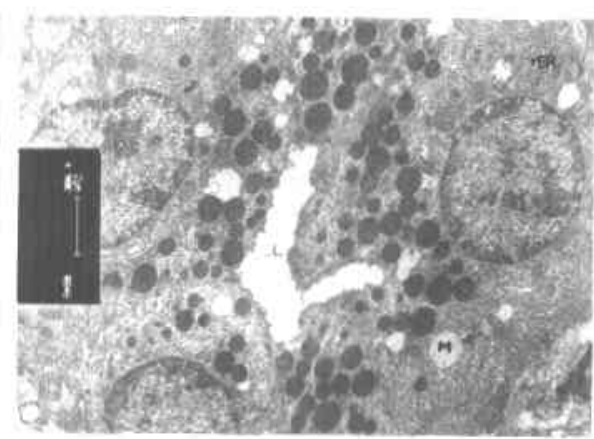

Fig. (10): An electronmicrograph of rat submandibular gland 2 weeks after operation, showing seromucous cells contain, irregular nucleus (n), few zymogen granules (Z), few dilated rough endoplasmic reticulum (rER), degenerated mitochondria $(M)$, vacuoles $(V)$ and lumen (L) of the acinus. Notice the regular nucleus $(\mathrm{N})$ of intact acinar cell. $(\mathrm{X}$ $6,000)$

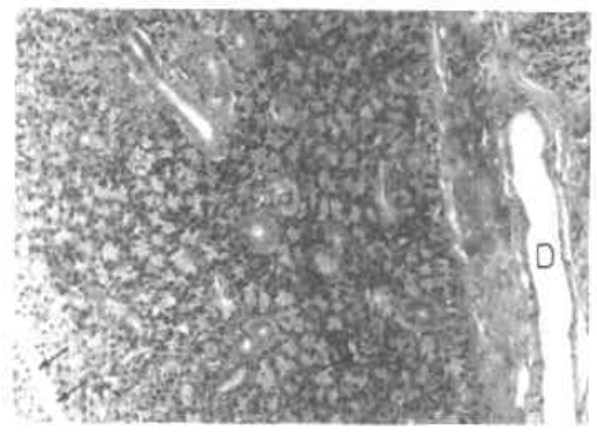

Fig. (12): A photomicrograph of a section of rat submandibular gland 4 weeks after operation, showing increased C. T. septa between lobules and around the acini (arrows), dilated interlobular ducts (D) and many striated ducts (d) among serous acini giving the gland of ductlike appearance. (HX. \& E.; X 100) 


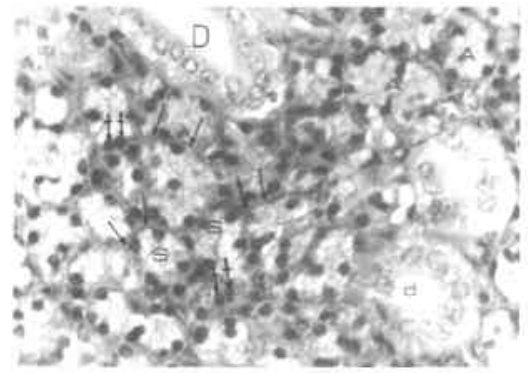

Fig. (13): A photomicrograph of a section of rat submandibular gland 4 weeks after operation, showing increased C. T. septa (arrows), atrophied acini (S) with nongranular vacuolated cytoplasm, dilated interlobular (D) and striated (d) ducts lined by atrophied cells and presence of apoptotic bodies (crossed arrows). Few intact acini (A) are seen. (HX. \& E.; X 400)

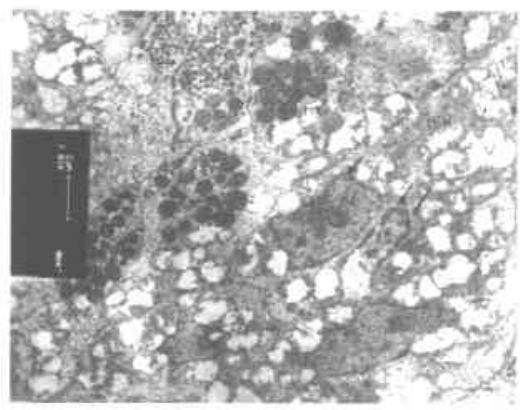

Fig. (15): An electronmicrograph in rat submandibular gland 4 weeks after operation, showing atrophied acinar cells contain irregular small nuclei $(\mathrm{N})$, bizarre of few small dark spherical zymogene granules $(Z)$, some degenerated mitochondria $(m)$, excess vacuoles $(V)$ and few rough endoplasmic reticulum ( $\mathrm{rER}$ ). Note: phagocytosed apoptotic bodies (arrows). (X 6,000)

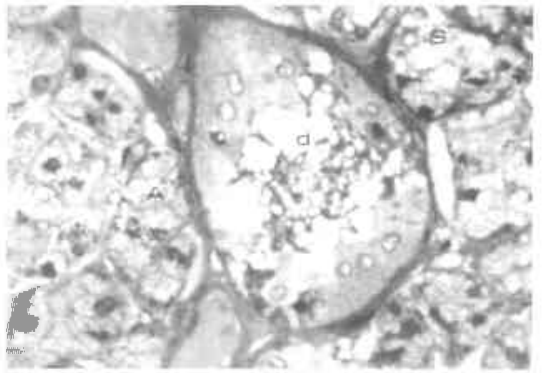

Fig. (14): A photomicrograph of semi thin section in submandibular gland of rat 4 weeks after operation. Note: atrophic acini (S) are lined by vacuolated cells, striated duct (d) with nongranular vacuolated cytoplasm and small nuclei arranged in more one layer. Persistent intact acinus $(A)$ is seen. (Toluidine blue; $X$ 1000)

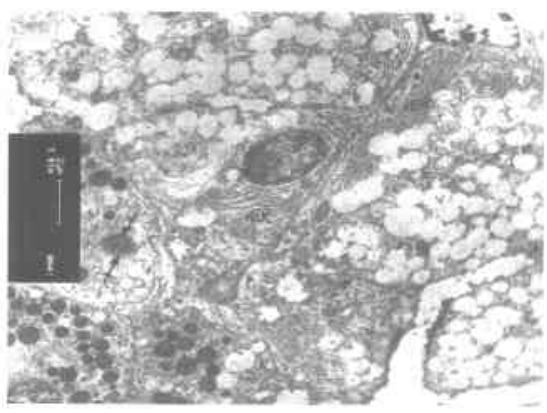

Fig. (16): An electronmicrograph of rat submandibular gland 4 weeks after operation, showing degenerated acinar cells contain dilated rough endoplasmic reticulum (rER), few of bizarre small dark zymogene granules $(Z)$, excess vacuoles (V). Note: nuclear chromatin aggregates into dense apoptotic bodies (arrows) and increased electron density in the cytoplasm (crossed arrows). The lumen (L) of atrophied seromucous acini is visible. $(\times 6,000)$ 


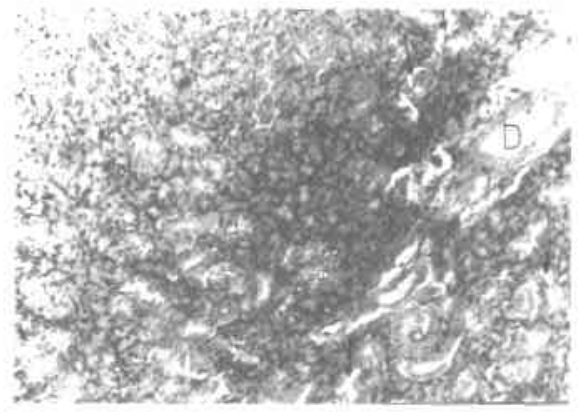

Fig. (17): A photomicrograph of a section of rat submandibular gland 8 weeks after operation, showing, increased $\mathrm{C}$. T. fibers (arrows) around atrophied acini and dilated interlobular ducts (D). Notice many striated ducts (d) giving the appearance of duct like structures. (HX. \& E.; X 100)

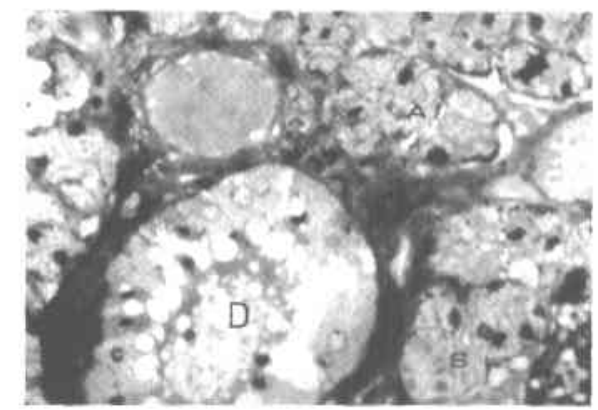

Fig. (19): A photomicrograph of semithin section in submandibular gland of rat 8 weeks after operation. Notice, atrophic acini (S) with nongranular vacuolated cytoplasm, the striated ductal cells (D) with small nuclei arranged in more than one layer. Persistent intact acinus $(A)$ is seen. (Toluidine blue; $X 1000$ )

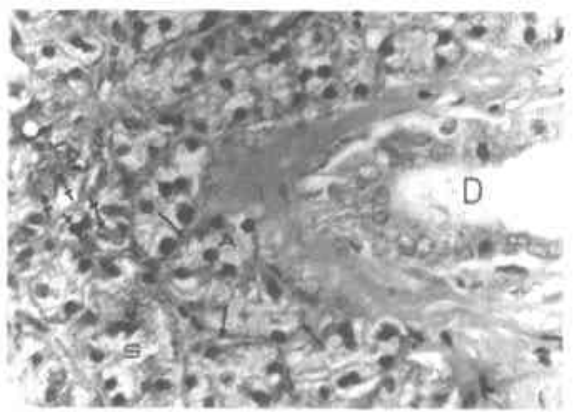

Fig. (18): A photomicrograph of a section of the submandibular gland of rat 8 weeks after operation showing, small non-granular vacuolated cytoplasm of cells lining the acini (S), dilated interlobular ducts (D) with increased amount of intralobular and interlobar connective tissue, atrophic acini (arrows) and apoptotic bodies (crossed arrows) in the acini. Intact acinus $(A)$ is seen. ( $H x$. \& $E_{\text {; }}$ X 400)

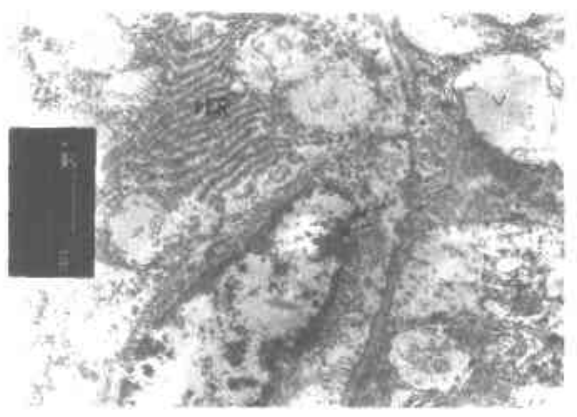

Fig. (20): An electronmicrograph in rat submandibular gland 8 weeks after operation, showing degenerated acinar cell contains irregular nucleus $(N)$, dilated rough endoplasmic reticulum ( $\mathrm{rER}$ ) and excess vacuoles (V). Notice, phagocytosed apoptotic bodies (arrows). (X 6,000) 


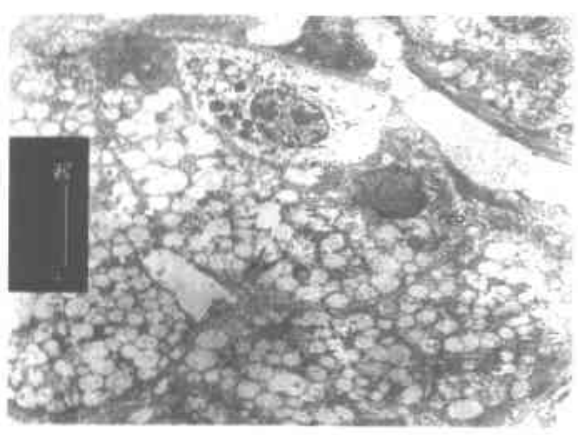

Fig. (21): An electronmicrograph of rat submandibular gland 8 weeks after operation, showing degenerated acinar cell with small irregular nucleus $(\mathrm{N})$, few zymogen granules (Z), dilated rough endoplasmic reticulum (rER) and increased electron density (arrows) in the cytoplasm and excess vacuoles. An intact small nucleus $(n)$ is seen. $(X$ 2,500 )

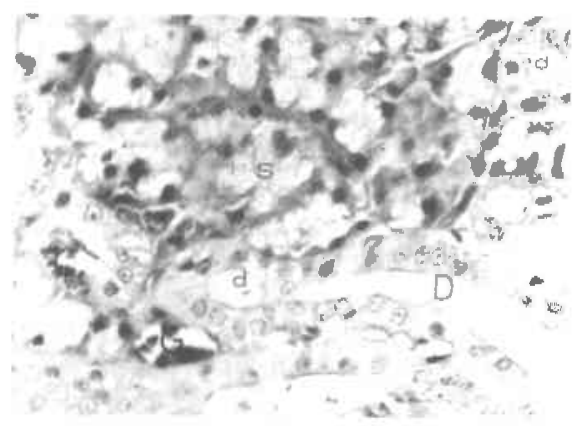

Fig (23): A photomicrograph in a section of rat submandibular gland 4 weeks after operation. Weak positive PAS reactivity in the acinar cells (S) and in striated (d) and interlobular (D) ducts. Moderate reactivity in granular convoluted tubules (G). (PAS; X 400)

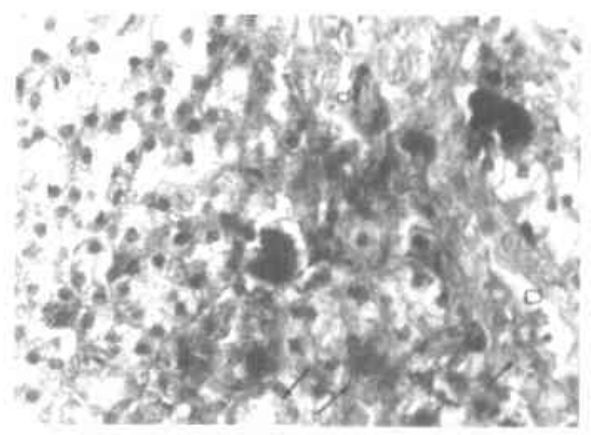

Fig (22): A photomicrograph of a section of rat submandibular gland 2 weeks after operation. Weak positive PAS reactivity in cytoplasmic granules of the acinar cells (arrows) and in striated (d) and interlobular (D) ducts. Moderate reactivity in granular convoluted tubules (G). (PAS; X 400)

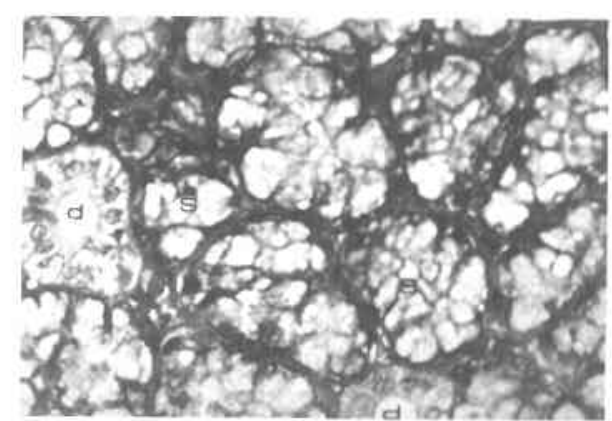

Fig (24): A photomicrograph of a section of rat submandibular gland 8 weeks after operation. Weak positive PAS reactivity in the acinar cells (S) and in striated ducts (d). (PAS; X 400) 


\section{DISCUSSION}

The chorda tympani branch of facial nerve is generally assumed to contain the preganglionic supply to the submandibular gland (Calvert et al., 1998). Interruption of parasympathetic nerve supply to the submandibular gland through destruction of chorda tympani nerve resulted in atrophy of the submandibular and sublingual glands (Kyriacou et al., 1986) and reduction of their secretory function (Zalin and Cooney, 1974).

In the present work, most of the submandibular acini showed progressive atrophic changes after transection of the chorda tympani nerve, while few persistent acini and ducts were still present among the atrophied ones. The atrophic acini appeared small and lined by vacuolated cells with presence of apoptotic bodies. This is concomitant with studies of Eitschberger (1981) as well as Kyriacou and Garrett (1988) who suggested that loss of acinar cells caused shrinkage of the acini in submandibular gland after preganglionic parasympathetic blockade.

In semi-thin sections stained with toluidine blue the granules of the acinar cells progressively decreased till disappeared four weeks after tympanic neurectomy. This observation is concomitant with that of Konig and Masuko (1997) who noticed disappearance of granules in the acinar cells with heterogeneity of ductal granules.

Ultra-thin sections of atrophied glands showed poorly developed organelles in their secretory cells. There were few dilated rough endoplasmic reticulum, degenerated mitochondria, less zymogen granules, irregular small nuclei with vacuolated cytoplasm and presence of phagocytosed apoptotic bodies within the cells four weeks after the operation. This is in agreement with the findings of Garrett (1963), Walker et al. (1988), Konig and Masuko (1997) and Takahashi et al. (2000).

Further evidence that the secretory fibers pass to the submandibular gland through the submandibular ganglion has been provided by many authors. Toremalm and Bjerre (1976) found that the submandibular gland secretion evoked by gustatory stimulation was reduced to $20-30 \%$ after sectioning the chorda tympani. Diamant and Kumlien (1974) followed up the patients after radical surgery for chronic otitis media and fenestration operation for otosclerosis, and noticed a significant decrease in the flow of submandibular saliva. In contrary, Ross (1970) reported that stimulation of chorda tympani nerve did not produce any increase of the resting flow rate of the submandibular saliva.

The persistent acini that were observed in this work seem to be not due to regeneration phenomenon of the nerve because a sufficient segment of chorda tympani nerve was cut during the operation to prevent postoperative regeneration of the nerve. The presence of intact acini and ducts 
may indicate that the submandibular gland receives parasympathetic fibers through other routes beside the chorda tympani nerve The existence of unknown parasympathetic nerves outside the chorda tympani was suggested by Hanna et al. (1999). Moreover, several observations suggested that the parasympathetic secretory fibers reach the submandibular gland by other routes beside the chorda tympani nerve (Garrett and Kyriacou, 1988; Boron and Boul Peep, 2003). Golding-Wood (1963) as well as Arulpragasm (1967) recommended the combination of chorda tympani nerve section with tympanic plexus destruction for the treatment of submandibular fistula. It is possible to postulate that there is a communicating branch between the chorda tympani nerve and the preganglionic tympanic nerve before reaching the tympanic plexus. However, the exact site of this communication is not settled and needs further investigation. Several observations suggested that the parasympathetic secretory fibers reach the cat submandibular gland by routes other than lingual nerve (Sato et al. 2001). The proportion of these fibers outside the lingual nerve seems to be different according to the animals used. Eitschberger (1981) as well as Kyriacou et al. (1986) reported that the acini of the submandibular gland did not show any degenerative changes after transection of the lingual nerve. The pathway of these secreto-motor fibers through the chorda tympani nerve to the submandibular gland was not defined. There may be afferent fibers in the chorda tympani which extend between the superior and inferior salivary nuclei in the brain stem, or pass through a communication at the level of the branches of the seventh and ninth cranial nerves.

In conclusion: by the aid of light and electron microscopy, the present study showed that the parasympathetic innervation of the majority of the submandibular acini is through the chorda tympani innervation. The presence of few persisting acini denotes other parasympathetic innervation to the gland beside the chorda tympani nerve.

\section{SUMMARY}

Twenty adult male rats were used in this study. Fifteen rats were exposed to right transtympanic chorda tympani neurectomy, and five rats were subjected to sham operation and used as control. The animals were sacrificed at 2, 4, and 8 weeks after the operation. At the assigned time, the submandibular glands were thoroughly dissected out and removed. Specimens from the gland were prepared for paraffin sections and stained with Haematoxylin and eosin and PAS stains. Other specimens were taken and proceeded for semi-thin sections (stained with toluidine blue) and for ultrathin sections (for electron microscopy).

Most of the submandibular acini showed progressive atrophic changes after transection of the chorda tympani nerve, while few persistent acini were still present among the atrophied ones. The atrophic acini ap- 
peared small and lined by vacuolated cells with presence of apoptotic bodies. The ducts were atrophied with dilated lumina. The acini and ducts are surrounded by thick connective tissue.

In semi-thin sections stained with toluidine blue the granules of the acinar cells progressively decreased till disappeared four weeks after operation.

E.M. examination of the atrophied gland showed poorly developed organelles in its secretory cell. There were few dilated rough endoplasmic reticulum, degenerated mitochondria, less zymogene granules and irregular small nuclei. The cytoplasm was vacuolated, and apoptotic bodies were present in specimens four weeks after the operation.

The present study showed that the parasympathetic innervation of the majority of the submandibular acini was through the chorda tympani innervation. The presence of few persisting acini after denervation denotes other parasympathetic innervation to the gland beside the chorda tympani nerve.

\section{REFERENCES}

1. Arulpragasam, A. C. (1967): On treatment of parotid fistula. J. Laryngol., 81:329-337.

2. Anderson, L. C. and Garrett, J. R. (1998): Neural regulation of blood flow in the rat submandibular gland. Eur. J. Morphol., 36:213-218.

3. Barton, S.; Sanders, E. J.; Schachter, M. and Uddin, M. (1975): Autonomic nerve stimulation, kallikrein content and acinar cell granules of the cat's submandibular gland. J. Physiol., 251(2):363-369.

4. Boron, W. F. and Boul peep, E. L. (2003): Pancreatic and salivary glands. Medical physiology: A cellular and molecular Approach. Saunders, London, Chp., 42: 908-930.

5. Calvert, P. A.; Heck, P. M. and Edwards, A. V. (1998): Autonomic control of submandibular protein secretion in the anaesthetized calf. Exp. Physiol., 83:545-556.

6. Carpenter, G. H.; Proctor, G. B.; Anderson, L. C.; Zhang, X. S. and Garrett, J. R. (2000): Immunoglobulin A secretion into saliva during dual sympathetic and parasympathetic nerve stimulation of rat submandibular glands. Exp. Physiol., 85 (3):281-286. 
7. Diamant, $H$. and Kumlien, A. (1974): A treatment for drooling on children with cerebral palsy. J. Laryng. Otolaryngol., 13:61-64.

8. Eitschberger, E. (1981): The sublingual and submandibular glands after preganglionic parasympathetic blockade: A histological, electron optical, auto radiographic and scintigraphic study on the guinea pig. Morphol. Med., 1(2):117-126.

9. Garrett, J. R. (1963): The ultrastructure of intracellular fat in the parenchyma of human submandibular salivary gland. Arch. Oral Biol., 12:14171436.

10. Garrett, J. R. and Kyriacou, K. (1988): Paralytic secretion after parasympathectomy of rabbit submandibular glands includes a cholinergic component. J. Exp. Physiol., 73(5): 737-746.

11. Golding-Wood, P. H. (1963): Tympanic neurectomy. J. Laryngol. Otolaryngol, , 76: 683-693.

12. Hanna, S. J.; Brelen, M. E. and Edwards, A. V. (1999): effects of reducing submandibular blood flow on secretory responses to parasympathetic stimulation in anaesthetized cats. Exp. Phsiol., 64(4):677-687.

13. Hayat, M. A. (1970): Principles and Techniques of Electron Microscopy. No Strand-Reinhold, Princeton, New Jersey., Vol., 1: 22-26.

14. Hellman, J. E. and Stomblad, B. C. R. (1960): Secretion from human submaxillary gland after section of the chorda tympani. J. Appl. Physiol., 15:297-305.

15. Holmberg, J. (1971): The secretory nerves of the parotid gland of the dog. J. Pysiol., 219: 463-476.

16. Izumi, H. and Karita, K. (1994): Salivary secretion in cat submandibular gland mediated by chorda tympani afferents. Am. J. Physiol., 268(2): $438-444$.

17. Konig, J. B. and Masuko, T. S. (1997): Ultrastructure of parotid and submandibular glands of old world Marten. J. Anat. Embryol., 102(1): 4957.

18. Kopka, S. L.; Germ, L. C. and Spector, A. C. (2000): Functional status of the regenerated chorda tympani nerve as assisted in the salt state discrimination task. Am. J. Physiol. Integr. Comp. Physiol, 278:720-731. 
19. Kyriacou, K.; Garrett, J. R. and Gjöstrup, P. (1986): Structural and functional studies of the effects of parasympathetic nerve stimulation on rabbit submandibular salivary glands. Arch. Oral Biol., 31(4):235-244.

20. Kyriacou, K. and Garrett, J. R. (1988): Morphological changes in the rabbit submandibular gland after parasympathetic or sympathetic denervation. Arch. Oral Biol., 33:271-280.

21. Luft, J. H. (1961): Ruthenium red and violet. I. Chemistry, purification methods of use for electron microscopy and mechanism of action. Anat. Rec., 171 (3): 347-368.

22. Millonig, G. J. (1961): A modified procedure for lead staining of thin sections. J. Biophys., Biochem, Cytol., 11: 736-739.

23. Perwaiz, S. A. and Karim, M. A. (1982): Localization of parasympathetic preganglionic neurons innervating submandibular gland in the monkey. Brain Res., 251:249-252.

24. Ross, J. A. T. (1970): The function of tympanic plexus as related to Frey's syndrome. Laryngoscope, 80:1816-1833.

25. Sato, A.; Izumi, H.; Nakamura, I. and Karita, K. (2001): Differences in parasympathetic vasodilator and salivary responses in cat submandibular gland between lingual and chorda-lingual nerve stimulation. J. Dent. Res., 80 (2):484-499.

26. Takahashi, S.; Nakamura, S.; Suzuki, R.; Islam, N.; Domon, T.; Yamamoto, T. and Wakita, M. (2000): Apoptosis and mitosis of parenchymal cells in duct-ligated rat submandibular gland. Tissue Cell, 32(6):457-63.

27. Toremalm, N. G. and Bjerre, I. (1976): Surgical elimination of drooling. Laryngoscope, 1:104-112.

28. Walker, N. I.; Harmon, B. V.; Gobe, G. C. and Kerr, J. F. R. (1988): Patterns of cell death. Met. Archiev. Exp. Pathol., 13:18-54.

29. Williams, N. I.; Banister, L. H.; Berry, M. M.; Collin, P.; Dyson, M.; Dussek, J. E. and Ferguson, M. W. J. (1995): Alimentary system. Gray's Anatomy: Anatomical bases of medicine and surgery. $38^{\text {th }}$ ed. P. 16841698. Churchill Livingstone, London.

30. Zalin, H. and Cooney, T. C. (1974): Chorda tympani neurectomy- a new approach to submandibular salivary obstruction. Br. J. Surg., 61 (5):391-394. 


\section{الملخص العربهى}

\section{التغيرات الدقيقة في الحويصلات المصلية المخاطية للغدة تحت الفكية}

للجرذ بعد قطع العصب الحبلى الطبلى

إبراهيم عطية شعبان، عبد الحكيم زهرى جبر، حنان عبا الحكيم الجندى، رؤوف فكرى بلير

قـســم التتريح ، كلية الطب ، جامعة المنصورة

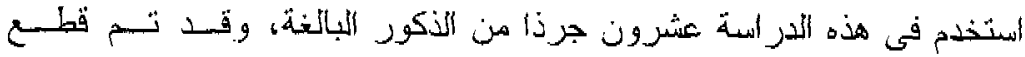

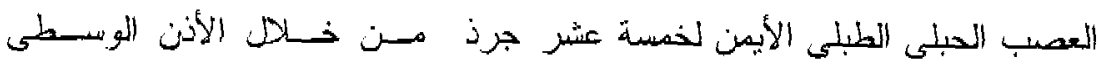

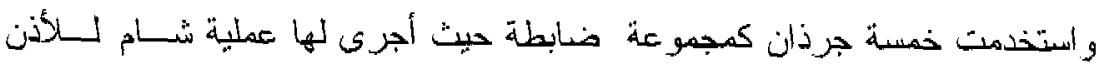

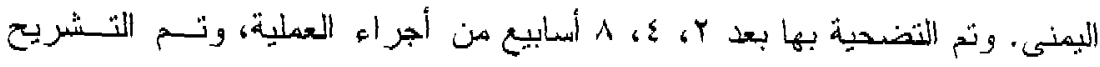

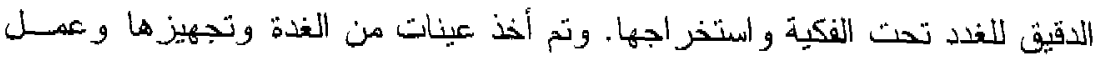

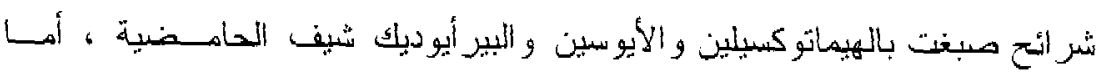

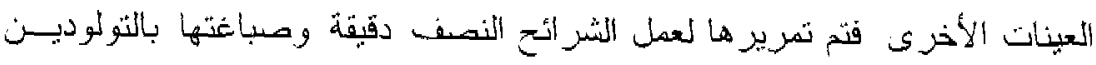

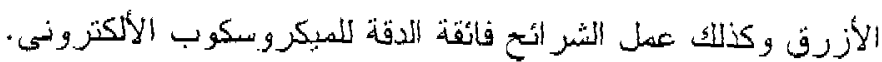

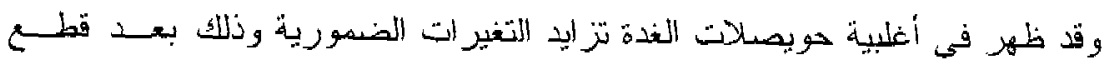

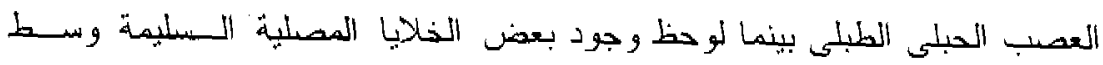

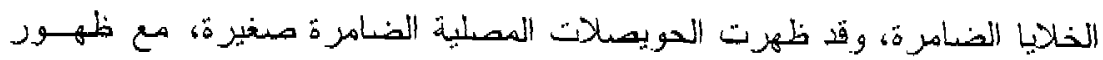

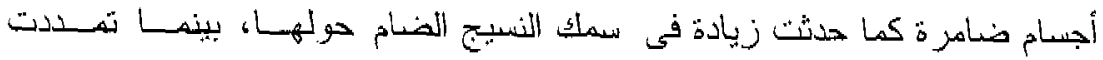
الفنو ات وكانت خلاباها ضاهمة.

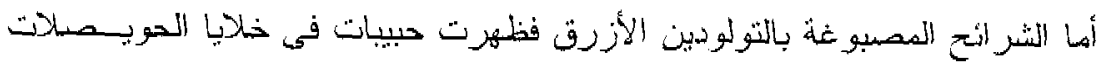

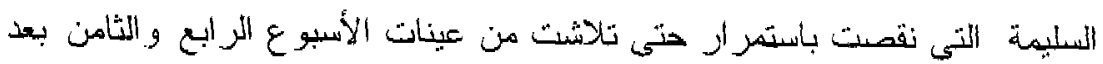
العطلية.

وبفص خلايا الحويصلات الضامرة بواسطة الميكروسكي ب الألكترونى فقد لوحظ

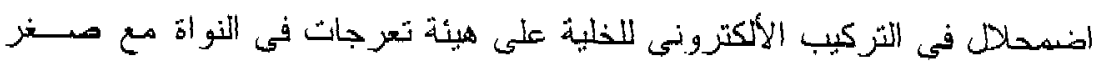


وضمور في المينوكي ندريا وقلة جبيبات الزيمو جين ووجود فر اغات بالـسيتو بلاز م

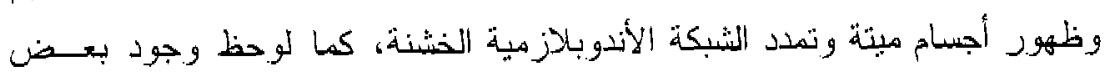
الخلايا المصلية السليمة.

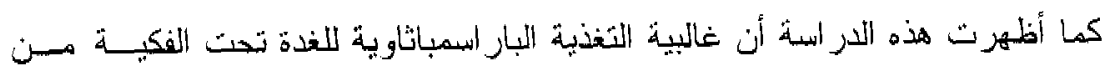

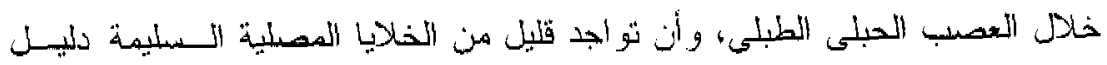
ملى وجود تغذية بار اسمباثاوية أخرى للغدة بالإضافة للعصب العبلى العبل الطبلى. 